\title{
Ulama Dalam Temuan Arkeologi Islam
}

\author{
Ahmad Cholid Sodrie
}

Keywords: islamic scholar, distribution, islam, manuscript, artifact

\section{How to Cite:}

Sodrie, A. C. Ulama Dalam Temuan Arkeologi Islam. Berkala Arkeologi, 15(3), 7073. https://doi.org/10.30883/jba.v15i3.674

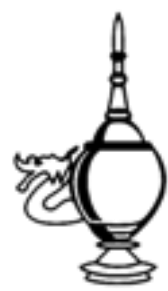

\section{Berkala Arkeologi}

https://berkalaarkeologi.kemdikbud.go.id/

Volume 15 No. 3, 1995, 70-73

DOI: $10.30883 /$ jba.v15i3.674 


\title{
ULAMA DALAM TEMUAN ARKEOLOGI ISLAM
}

\author{
Ahmad Cholid Sodrie \\ (Pusat Penelitian Arkeologi Nasional)
}

\section{Pendahuluan}

Ulama berasal dari bahasa Arab yang berarti orang yang berilmu pengetahuan luas dalam agama Isiam; sebagai Muballig dengan arti orang yang menyampaikan; sebagai Da'i dengan arti orang yang mengajak atau memanggil. Dengan demikian Ulama adalah seorang berilmu pengetahuan Islam yang luas, menyampaikan keilmuannya dengan moto Sampaikanlah dariku walau hanya satu ayat (al-Hadits), kemudian mengajak orang menerima apa yang ia sampaikan kedalam Islam secara keseluruhan (Al Baqarah,2:208). Selain itu ulama adalah pewaris para Nabi (alHadits).

Jawa dan Aceh merupakan daerah tumbuh dan berkembangnya Islam di Indonesia. Di Jawa para Ulama dikenal dengan para Wali (Wali Sanga $=9$ Wali Allah) seperti Sunan Gunung Jati untuk daerah Jawa Barat; Sunan Kali Jaga untuk daerah Jawa Tengah; dan Sunan Giri untuk daerah Jawa Timur. Sedangkan untuk Aceh dikenal nama-nama Hamzah Fansuri, Samsuddin as-Sumatrani dan Nuruddin ar-Raniri. Namun tidak menutup kemungkinan daerah-daerah lain di Indonesia terdapat para Ulama. Tinggalan naskah-naskah di daerah Aceh tersebar di seluruh pelosok, terutama di tempat-tempat pengkaderan ummat (Zawiyah atau Meunasah di Aceh, atau pesantren). Sebaran tempat penyimpanan (koleksi) naskah ditemui di tempat-tempat yang melatari masa silamnya, seperti Cirebon, Jawa Barat bekas pusat kerajaan dan pusat penyebaran Islam, Museum Geusan Ulun di Sumedang (koleksi naskahnya berasal dari masyarakat); Museum $\mathrm{Na}$ sional (kini naskah-naskahnya menjadi koleksi Perpustakaan Nasional) untuk DKI Jakarta; Museum Sonobudoyo untuk DI Yogyakarta; Pendopo Mesjid Agung Surakarta (naskahnya berasal dari bekas pesantren Mambaul 'Ulum) untuk daerah Jawa Tengah, dan beberapa kolektor dari koleksi naskah-naskah di seluruh Indonesia lainnya. Me-lalui data epigrafi dari batu nisan, kiranya dapat digunakan untuk merunut keberadaan para ula-ma di masa lampau.

\section{Ulama Dalam Data Tekstual}

Tinggalan masa lampau berupa naskah (manuscript) kaitannya dengan Ulama sangat erat. Naskah merupakan hasil karya dari para Ulama. Tempat menyampaikan dikenal dengan pesantren dan merupakan tempat tinggalnya. Keberadaan naskah dapat dihasilkan dari pe- nyampaian dan penerimaan (belajar mengajar) dan ketika sang Murid/Santri akan mengakhir: masa belajarnya di satu pesantren. Aceh dengan latarnya dapat menjawab fenomena tersebut, karena dalam kenyataan terkumpulnya naskah di Zawiyah Tanah Abe dalam beraneka judul mengacu pada perkembangan keilmuan yang diperlukan terutama dalam ilmu agama. Begitu pula naskah-naskah yang berhasil dikumpulkan Museum Negeri Aceh, melalui dana yang tersedia untuk keperluan tersebut. Naskah-naskah tersebut dapat mencerminkan keberaadan Aceh sebagai sebuah kerajaan bercorak Islam dan Aceh sebagai daerah pusat pengembangan dan penyebaran Islam di Nusantara. Dalam perkembangannya, Aceh diminati bukan saja dari dalam te-tapi Ulama dari luar yang datang dan mengembangkan keilmuannya di Tanah Rencong. Di antara mereka adalah Syekh Nuruddin ar-Raniry dan Hamzah Fansuri. Selain itu ada beberapa naskah yang dapat diperinci sebagai berikut.

1. Hamzah Fansuri dengan karyanya berjudul Zinatul Muwahhidin, naskah tentang tasawuf dengan ukuran $13 \times 20.5 \mathrm{~cm}, 39$ halaman dalam 2 kuras;

2. Syekh Nuruddin ar-Raniry dengan karyanya berjudul Bustanussalatin, naskah tentang ketatanegaraan yang menyangkut perundangundangan dan syarat-syarat seseorang menjadi Sultan atau Menteri dan sebagainya. Nas- kah Nuruddin lainnya berjudul Lata'ifful asrar, naskah tentang tarekat yang berukuran $16.5 \times$ $21.5 \mathrm{~cm}$, 9 halaman, dalam 1 kuras. Naskah yang berjudul Syifaulqulub naskah yang berisikan tentang tasawuf, berukuran $14.5 \times 20.5 \mathrm{~cm}$

Ulama asing lainnya adalah:

1. Syekh Saman Al Jamal al Jalalain dengan naskahnya berjudul Tafsirul Jalalain, naskah tentang tafsir Al Quran dengan ukuran $21.5 \mathrm{X}$ $20.5 \mathrm{~cm}, 500$ halaman, dengan 50 kuras,

2. Hujjatul Islam al Gazali dengan naskahnya berjudul Kitabut Tauhid wat Tawakkal, naskah tentang tasawuf dengan ukuran $17 \times 24 \mathrm{~cm}, 64$ halaman, dengan 3 kuras.

Tiga hal yang menjadi sebab perkembangan naskah adalah adanya seorang alim, dan sarana tempat menagajarkan ilmu dan santri yang menerima pelajaran. Kebutuhan terhadap alat pelajaran mengakibatkan Guru/Ulama itu membuat /menciptakan naskah atau menyalin naskah yang 
ada. Suatu tradisi yang hidup dikalangan Zawiyah bagi Santri/Murid yang akan selesai belajar, diwajibkan Guru/Tengku (Aceh) menyalin karya para Ulama terdahulu. Itulah mengapa di Zawi-yah Tanah Abe banyak ditemukan naskah karya Imam Gazali (Ihya Ulumuddin). Adakah kemung-kinan yang serupa dengan kasus di atas terhadap temuan beberapa naskah di Zawiyah Tanah Abe yang berkaitan dengan nama daerah lain di Indonesia? Naskah-naskah tersebut adalah:

- Sirrus Salikin, naskah tentang Tasawuf, dengan ukuran $13.5 \times 20.5 \mathrm{~cm}, 504$ halaman, 43 kuras, karya Syekh Abdu Samad Al-Falimbani; nas-kah berbahasa Arab dan Melayu.

- Mandoril Ajalli lla Rutbatil A'lam, naskah mengenai tasawuf dengan ukuran $16 \times 20 \mathrm{~cm}, 32$ halaman, 3 kuras. Naskah ini karya dari Jalaluddin Ibn A'rifubillah Khatib Al Asyi.

- Naskah karya Syekh Muhammad Arsyad Albanjari, dan naskah tentang tarikat berbahasa Jawa.

- Karya Ulama Banten berjudul fatul Muin Bi Syahril Kurratil A'in, naskah tentang fiqih dengan ukuran $25 \times 17,5,190$ halaman, dalam 14 kuras, karya Syekh Nawawi al-Bantani.

- Seorang Ulama besar Aceh yang kreatif yaitu Syekh Abdur Rauf Assingkili dan dikenal dengan sebutan Syekh Kuala. Karya-karya beliau berlandaskan pada mashab Syafi'i, disamping itu beliau juga sebagai seorang yang mengembangkan tasawuf Syatariah. Di antara karyanya adalah Mirratuttulab Fii Tasyil Ma'rifatal Ahkam Asysyariah, tentang fiqih dan tasawuf berjudul Daqoiqul Huruf dan Aghmadul Masail.

Naskah-naskah yang ditemukan di daerah Jawa, terutama di daerah Jawa Barat menunjang keberadaannya terhadap daerah temuan naskah tersebut Di daerah Cirebon dan sekitarnya banyak ditemukan naskah-naskah agama yang mempunyai ciri dan mengacu pada salah satu aliran atau mazhab yaitu naskah Fathul Qarib AlMujib bermazhab Syafii. Naskah serupa ditemukan di daerah Garut, pada koleksi Arif Muhammad di Cangkuang.

Cirebon mempunyai latar bekas pusat pemerintahan dan pusat penyebaran Islam dengan Kasepuhan dan Kanomannya, juga Krapyak Kaprabonan dan Kacirebonan. Dua nama terakhir diketahui sebagai tempat para santri menimba ilmu keagamaan.

Cangkuang dengan latar masa pra Islam berupa bangunan candi yang berdampingan dengan makam tokoh Arif Muhammad. Keberada-an Arif Muhammad di tempat tersebut melatari penyerangan pasukan Mataram ke Batavia dan berakhir dengan kegagalan. Malu pulang dengan kekalahan akhirnya memilih bermukim di tempat itu sambil mengembangkan ajaran Islam pada masyarakat Cangkuang. Temuan naskah-naskah di Jawa Barat pada umumnya berkisar pada naskah-naskah agama Islam dan tasawuf. Naskah fiqih karya ulama terkenal beraliran mazhab Syafii banyak ditemukan dan dikenal dengan kitab Takrib karya Al Imam Al Alamah Ahmad bin Al Husein Asyahir bi Abi Suja. Naskah tafsir Jalalain juga mewarnai temuan di Priangan Timur, selain beberapa naskah tasawuf dari tarekat Qodariah dan Nakhsabandiyah. Naskah-naskah Syekh Muhammad Arsyad Al Banjari pun banyak ditemukan dalam bentuk rangkuman pelajaran agama Islam secara praktis dengan judul Parukunan.

Temuan naskah di daerah tain yang mempunyai latar hubungan dengan kedatangan orangorang asing ke wilayah Nusantara adalah daerah Maluku. Ternate dan Tidore berlatar sebagai kerajaan Islam sejak abad ke 16 dengan rajanya Abuleis (Babullah?). Naskah-naskah Alquran mewarnai latar kerajaan Ternate dan Tidore, sedangkan naskah-naskah berjudul Qaulul Haq dan berisikan surat kepercayaan dari VOC di Batavia untuk Kerajaan Ternate, melatari monopoli perdagangan pihak Belanda. Naskah Al Quran yang ditulis oleh Ulama 'Afiffuddin Abdul Baqi bin Abdullah Al 'Adani, ditulis pada hari Senin 7 Dzul-qaidah tahun 1050 H (1640 M) di Makkah. Keberadaannya di Ternate, merupakan barang wakaf Haji Abdul Halim bin Abdul Hamid Imam Bagot Ternate pada abad ke-19 M (Sodrie, 1982:417. 443). Kasus di Maluku ini menarik, karena disatu pihak mereka datang untuk keperluan agama dan di pihak lain mereka datang karena perdagangan. Keduanya menggunakan tokoh yang berbeda yaitu ulama dan ekonom.

Konteks ulama dalam temuan batu-batu nisan dapat diklasifikasikan pada tipologi batu nisan dan kandungan tulisan pada batu nisan. Tipologi batu nisan di Jawa terutama mengacu pada bentuk batu nisan para wali. Para wali (Wali Sanga), merupakan kelompok masyarakat ulama yang mempunyai kelebihan dari Allah SWT dan dikenal dengan karomah. Para nabi dan para rosul Allah diberikan kelebihan mu'jizat yang kedudukannya lebih tinggi dari karomah para ulama. Kajian melalui batu nisan para wali di Jawa. bentuknya memiliki beberapa persamaan. Secara garis besar batu nisannya pipih dengan hiasan dan pola yang banyak. Tipe tersebut ditemukan di kompleks makam belakang Masjid Agung Demak, seperti batu nisan Raden Patah dan Sunan Kali Jaga di Kadilangu. Badan makam atau kijing berundak dan berhiaskan antevik. Sayangnya batu-batu nisan para wali itu hampir keseluruhan-nya tidak ada data tertulis yang dapat merunut siapa, dan kapan berpulang ke Rahmatullah. Ha-nya 
sebuah makam yang dipenuhi dengan hias-an dan tulisan yaitu makam Malik Ibrahim di Gre-sik, Jawa Timur. Beliau dipercayai sebagai seo-rang ulama dan seorang penguasa pada masa-nya. Hal itu dapat diketahui dari beberapa gelar yang diterakan pada batu nisannya terutama ge-lar Maulana yang mempunyai konotasi seorang ulama, kemudian dihubungkan dengan gelarnya yang lain: Burhanuddulah Waddin pelindung negara dan agama. Gelar itu juga mempunyai arti bahwa beliau disamping seorang ulama juga seorang penguasa

Dari penelitian di Barus Tapanuli Tengah, ditemukan dua buah makam. Sebuah di kompleks makam Papan Tinggi dan yang sebuah lagi di Situs Tuanku Ambar. Batu nisan di situs Papan Tinggi sepasang dengan bentuk yang berbeda, dari batu granit. Dari tulisan diketahui na-ma yang dimakamkan adalah Syekh Mahmud, juga memuat do'a, hadits Qudsi, hadits Nabi, la-fad Tauhid, juga nama gelaran yang disandang-nya tertera Syekh dan Al 'Alim. Konotasi kedua gelar ini saling menguatkan satu dengan lainnya dalam hubungannya dengan ulama. Makam di Kompleks Tuanku Ambar diawali surat Al Imran ayat 18, nama yang meninggal diawali gelar Syekh dengan perkiraan nama Syekh Jalaluddin (?), dan lafad Tauhid.

Batu nisan di Brunei Darussalam, terdapat beberapa yang diperkirakan berkaitan dengan makam seorang ulama. Pada bahasan batu-batu kubur di Seminar Brunei Dalam Sejarah I, menyebutkan adanya tiga bentuk batu kubur.

1. Batu kubur Sultan dengan ciri berhiaskan suIuran daun merambat atau dikenal dengan Air Mulih di Brunei. Pada bagian atasnya terdapat hiasan bunga teratai kuncup. Sedang pada tulisan yang tertera ditemukan gelaran yang menyatakan ia seorang Sultan (Sultan Bolkiah, Sultan ke 5).

2. Batu kubur ulama dengan batu pipih tanpa hiasan, namun pada batu kuburnya terlihat hiasan ayat, hadits dan syair tentang kelebihan seorang yang alim (ulama). Selain itu gelar yang disandangnya menunjukkan profesi sebagai seorang yang tinggi ilmu pengetahuannya dalam agama; seperti Al Fagih Al Qodli dan sebagainya (Imam Yaqub di situs Kotabatu; Sodrie, 1994). Namun temuan lain di situs kompleks makam Kianggeh ternyata mempunyai kriteria lain yaitu: batu kuburnya berhiaskan bunga teratai di bagian atasnya dan hiasan suluran (air mulih) di bawah bunga teratai. Tulisan yang tertera berisikan ayat dari Surat $\mathrm{Al}$ Baqarah: 255 atau yang dikenal dengan ayat Kursi. Bacaan Basmalah pada sisi lain-nya (batunya hanya sebuah) kemudian dilan-jutkan dengan do'a. Di dalam do'a tersebut ter-selip kata-kata Aulia Al-Kiram (para walimu yang mulia, dapat pula diterjemahkan dengan para penyampaimu). Selain itu sebuah batu kubur di Brunei yang terkait dengan identitas seorang ulama, yaitu batu kubur Sultan Syarif Ali. Semasa beliau hidup, ia adalah seorang alim, sehingga beliau dijuluki Seorang yang Berkat (keramat di Indonesia). Pada batu ku-burnya selain nama $\mathrm{Ha} / \mathrm{Sya} / \mathrm{ri} / \mathrm{f}$ Ali juga tarekh wafat(lindung)nya yaitu \pm abad $15 \mathrm{M}(836 \mathrm{H})$. Pada bagian pinggirannya dihiasi tulisan syair yang menyatakan bahwa: Manusia semuanya akan mati kecuali orang-orang yang berilmu. dan orang-orang yang berilmu mereka akan mati kecuali orang-orang yang beramal, orangorang yang beramal itupun akan mati kecuall orang-orang yang ikhlas, orang-orang yang ikhlas itu adalah khatar yang Maha Agung Tulisan itu terdapat pada kedua muka-nya denga lafad-lafad Tauhid dan Allah.

\section{Penutup}

Singgahan awal Islam ke Indonesia, balk pertama masuknya, sejak abad 1 Hijrah maupun pada abad ke-13, masing-masing mempunyai alasan dan data kuat yang melatarinya. Faham ataupun mazhab yang melatari, secara langsung dibawanya serta. Itulah sebabnya ada pendapat menyatakan suffisme datang ke Indonesia bersamaan dengan persinggahan awal Islam itu sen-dirı (John, 1957:1-111). Bersamaan itu pulalah kiranya para ulama memulakan dakwahnya di tempat awal/tempat persinggahan lainnya.

Ulama sebagai orang yang mewarisi para nabi dalam islam dapat dirunut melalui temuan epigrafis arkeologis (Historical Archaeologis) baik dalam naskah-naskah yang tersebar dari ujung utara Pulau Sumatera, Jawa sampai daerah Maluku dan Kalimantan bagian utara yaitu Brunei Darussalam. Mereka dikenal dengan Wali. al Faqih, Imam, Syekh, Maulana, al Alim, dalam bentuk istilah setempat dikenal gelar Tengku, Kyai

Keberadaan ulama membawa keberuntungan dalam pendidikan, terutama dalam bidang tulis baca. Sarana yang ada berupa tempat belajar di satu pihak dan naskah sebagai alat belajar di pihak lain, dua hal yang perlu dilestarikan keberadaannya sebagai sarana belajar dan mengajar di masa silam.

Naskah-naskah tasawuf/tarekat dan tulisan-tulisan berupa ayat Al Quran, Al Hadits dan syair-syair pada batu-batu nisan/kubur, memperkuat pendapat bahwa ajaran tasawuf merupakan salah satu saluran islamisasi di Indonesia, semuanya itu mengacu pada peran para ulama yang ditemukan konteksnya dalam temuan ar-keologis. 
Kedudukan ulama di masa lalu tidak dapat disamakan kedudukannya dengan ulama sekarang, dengan tidak mengurangi rasa hormat kepada mereka yang masih memelihara kriteria ulama masa lalu dengan segala propertinya lahir batin. Tiada ulama yang dapat menilai keulama-an seorang ulama kecuali ulama yang benar-benar ulama.

\section{KEPUSTAKAAN}

Aba Syuja, Ahmad bin Al-Husain As-Syahrir, 1938. Fathul Qarib Al-Mujib. Cirebon, AlMaktabah Al-Misriyah.

Ahmad Qadhi, Abdurahim,tt. Daqaiqu Al-Akhbar fi dzikril Jannati wannar, Surabaya 'Awadh bin Abdillah At-Tamimi

Ambary, Hasan Muarif, 1981. Pendekatan arkeologi Dalam Penelitian Agama di Indone-sia. Penelitian Agama Masalah dan Pemikiran. Jakarta, Sinar Harapan.

1984. L'Art Funeraire Mu-sulman En Indonesie Des Origines Au XIX Siecle. Tesis Ph.D. Ecole Des Hautes Etudes En Sciences Sociales Paris.

Departemen Agama, 1985/1986. Al-Quran dan Terjemahannya. Jakarta, Intermas.

Damais, L. Ch., 1957. Etudes Javanaises I, Les Tombes Musulmans datees de Tralaya. BEFEO XLVII fasal 2, Paris. Him. 353-415.
Othman Mohd. Yatim dan Abdul Halim Nasir. 1990. Epigrafi Islam Terawal di Nusantara Kuala Lumpur, Dewan Bahasa dan Pustaka Kementrian Pendidikan Malaysia.

Sodrie, Ahmad Cholid, 1991. Nisan-nisan Islam Brunei Darussalam: Suatu Perbandingan. Seminar Brunei dalam Sejarah I Brunei Darussalam, Akademi Pengajian Brunei Universiti Brunei Darussalam dan Persatuan Sejarah Brunei Negara Brunei Darussalam

1994. Hubungan Indonesia Dengan Brunei Darussalam Melalui Kajian Inskripsi par da Batu Nisan Seminar Evaluasi Data dan Interpretasi Baru Sejarah Kuna Yogyakarta, Balai Arkeologi.

1994. Kajian Studi Epigrafi Masa Islam Kasus Batu Tarsilah di Brunei Darussalam.

Evaluasi Hasil Peneliti-an Arkeologi. Palembang, Balai Arkeologi

Uka Tjandrasasmita, 1976. Sejarah Nasional III. Jakarta, Departemen Pendidikan \& Kebudayaan 